Dublin Institute of Technology

ARROW@DIT

2007-01-01

\title{
Modulation of Radiation Responses by Pre- Exposure to Irradiated Cell Conditioned Medium
}

Paula Maguire

Dublin Institute of Technology

Carmel Mothersill

Dublin Institute of Technology

B. McClean

St. Luke's Hospital, Dublin

C. Seymour

St.Luke's Hospital, Dublin

Fiona Lyng

Dublin Institute of Technology, Fiona.lyng@dit.ie

Follow this and additional works at: http://arrow.dit.ie/radart

Part of the Radiology Commons

\section{Recommended Citation}

Maguire, P. et al. (2007) Modulation of Radiation Responses by Pre-Exposure to Irradiated Cell Conditioned Medium. Radiation Resarch, Vol. 167, no. 4, pp.485.492. DOI:10.2307/4138649

This Article is brought to you for free and open access by the Radiation and Environmental Science Centre at ARROW@DIT. It has been accepted for inclusion in Articles by an authorized administrator of ARROW@DIT. For more information, please contact yvonne.desmond@dit.ie,

arrow.admin@dit.ie.

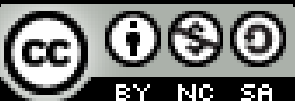




\title{
Modulation of Radiation Responses by Pre-exposure to Irradiated Cell Conditioned Medium
}

\author{
Paula Maguire, ${ }^{a, 1}$ Carmel Mothersill,${ }^{a, b, 2}$ Brendan McClean, ${ }^{b}$ Colin Seymour ${ }^{a, b, 2}$ and Fiona M. Lyng ${ }^{a}$ \\ ${ }^{a}$ Radiation and Environmental Science Centre, Dublin Institute of Technology, Dublin 8, Ireland; and ${ }^{b}$ St. Luke's Hospital, Rathgar, \\ Dublin 6, Ireland
}

\begin{abstract}
Maguire, P., Mothersill, C., McClean, B., Seymour, C. and Lyng, F. M. Modulation of Radiation Responses by Pre-exposure to Irradiated Cell Conditioned Medium. Radiat. Res. 167, 000-000 (2007).
\end{abstract}

The aim of this study was to investigate whether exposure of HPV-G cells to irradiated cell conditioned medium (ICCM) could induce an adaptive response if the cells were subsequently challenged with a higher ICCM dose. Clonogenic survival and major steps in the cascade leading to apoptosis, such as calcium influx and loss of mitochondrial membrane potential, were examined to determine whether these events could be modified by giving a priming dose of ICCM before the challenge dose. Clonogenic survival data indicated an ICCMinduced adaptive response in HPV-G cells "primed" with 5 mGy or 0.5 Gy ICCM for $24 \mathrm{~h}$ and then exposed to $0.5 \mathrm{~Gy}$ or 5 Gy ICCM. Reactive oxygen species (ROS) were found to be involved in the bystander-induced cell death. Calcium fluxes varied in magnitude across the exposed cell population, and a significant number of the primed HPV-G cells did not respond to the challenge ICCM dose. No significant loss of mitochondrial membrane potential was observed when HPV-G cells were exposed to $0.5 \mathrm{~Gy}$ ICCM for $24 \mathrm{~h}$ followed by exposure to 5 Gy ICCM for 6 h. Exposure of HPV-G cells to 5 mGy ICCM for $24 \mathrm{~h}$ followed by exposure to 0.5 Gy ICCM for $18 \mathrm{~h}$ caused a significant increase in mitochondrial mass and a change in mitochondrial location, events associated with the perpetuation of genomic instability. This study has shown that a priming dose of ICCM has the ability to induce an adaptive response in HPV-G cells subsequently exposed to a challenge dose of ICCM. $\odot 2007$ by Radiation Research Society

\section{INTRODUCTION}

The adaptive response is defined as a "protective effect" after exposure of cells to a low "priming" dose of a stress inducer (1). The first experiment on the induction of an

\footnotetext{
${ }^{1}$ Address for correspondence: Radiation and Environmental Science Centre, Focas Institute, DIT Kevin St., Dublin 8, Ireland; e-mail: pmaguir@tcd.ie.

${ }^{2}$ Present address: Medical Physics and Applied Radiation Sciences Unit, McMaster University, 1280, W. Main Street, Hamilton, ON L8S 4K1, Canada.
}

adaptive response caused by exposure to ionizing radiation was carried out in human lymphocytes that had incorporated tritiated thymidine (2). It was found that approximately half as many chromosome aberrations were induced in irradiated cells that had first been exposed to a low priming dose compared to those that had not been pre-exposed. This led to the finding that pretreatment of lymphocytes to a dose of the order of centigrays of $\mathrm{X}$ rays could cause the cells to have a less severe response to a higher dose (3). Adaptive responses have also been reported in $\mathrm{C} 3 \mathrm{H}$ $10 \mathrm{~T} 1 / 2$ cells pretreated with low-dose $\gamma$ radiation followed by a challenge dose $(4,5)$. Mitchel et al. (6) showed that pre-exposure to a chronic 10-cGy dose followed by a challenge chronic dose of $1 \mathrm{~Gy} 24 \mathrm{~h}$ later could increase the latent period for development of acute myeloid leukemia in $\mathrm{CBA} / \mathrm{H}$ mice.

Certain characteristics have emerged from studies of the adaptive response. A variable interval is needed to induce an adaptive response. This has been observed to be 4 to 6 $\mathrm{h}$, continuing in some cases for up to $20 \mathrm{~h}$ (7) or even 40 days (8). Radiation can interact with other stress inducers such as chemical agents to induce an adaptive response (9). Adaptive responses can be inhibited by the presence of poly (ADP-ribose) polymerase inhibitors, protein or RNA inhibitors and protein kinase $\mathrm{C}$ inhibitors (10). It has been observed that new proteins are synthesized after exposure to a low priming dose (11). It has been postulated that if the priming dose is low enough to cause damage, but not extensive cellular damage, and enough time is given for the cells to respond, an efficient repair system could be induced. This occurs through the induction of protein synthesis consequent to the activation of specific genes. If sufficient time for protein synthesis is not allowed, then the protein machinery necessary for repair will not be activated. Ikushima et al. (12) observed that the rate of rejoining of DNA double-strand breaks was higher in cells primed with a low dose compared to those receiving no priming dose.

The bystander effect has been defined by Mothersill and Seymour (13) to be the detection of a response in unirradiated cells that can reasonably be assumed to have occurred as a result of exposure of other cells to radiation. 
MAGUIRE ET AL.

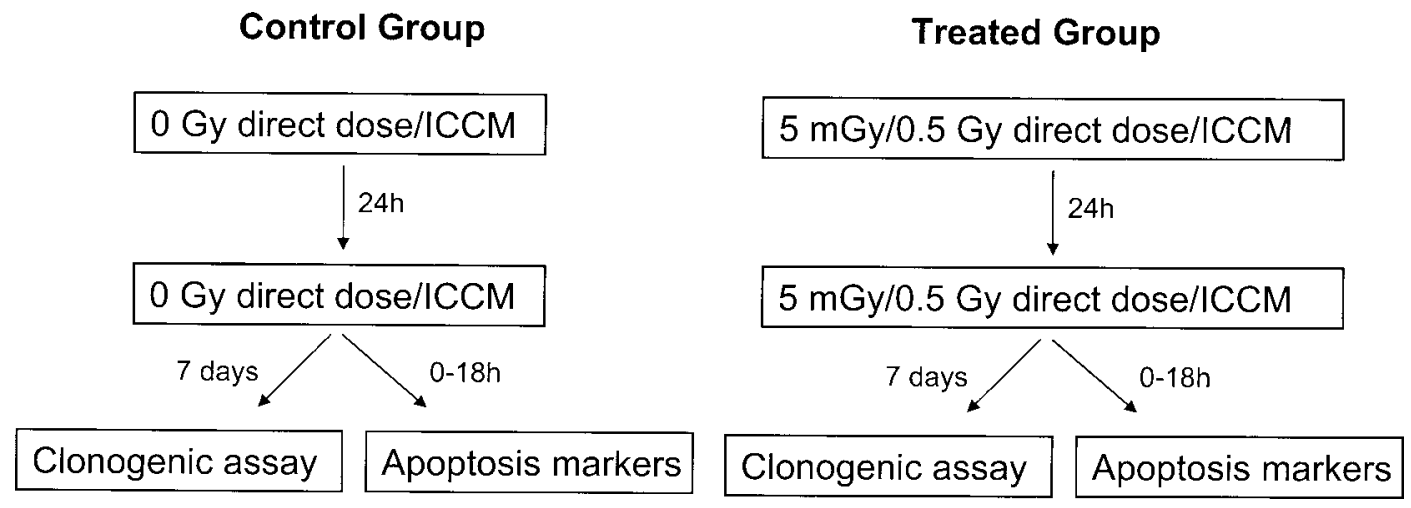

FIG. 1. Flow chart showing the experimental procedures for primed samples.

The bystander signal molecule(s) is known to cause sister chromatid exchanges (14), chromosomal aberrations (15), changes in protein expression (16), genomic instability (17), and initiation of apoptosis and loss of mitochondrial membrane potential (18). The data suggest that the bystander effect saturates at low doses and is the dominant effect of low-dose radiation $(19,20)$.

Sawant et al. (21) reported that a priming dose of 2 cGy $\gamma$ rays delivered $6 \mathrm{~h}$ before microbeam irradiation cancelled out half of the observed bystander-induced cell death. A subsequent study (22) showed that a low dose of $\mathrm{X}$ rays delivered $4 \mathrm{~h}$ before microbeam irradiation significantly decreased bystander mutagenesis. In addition, it has been shown that bystander signals produced by irradiated cells can protect against a direct dose of ionizing radiation (23). A recent paper by Mitchell et al. (24) reported a 95\% decrease in cell killing when $\mathrm{C} 3 \mathrm{H} 10 \mathrm{~T} 1 / 2$ cells were pretreated with 2 cGy of $\alpha$ particles $24 \mathrm{~h}$ before exposure to 0.5 Gy $\alpha$-particle radiation. This study also reported that treatment with medium from cells exposed to $2 \mathrm{cGy} \mathrm{X}$ rays can induce a "bystander adaptive response" in C3H 10T1/2 cells against a higher dose of direct radiation (4 Gy X rays). Iyer and Lehnert (25) reported that when normal human lung fibroblasts (HFL-1) were irradiated with $1 \mathrm{cGy}$ of $\gamma$ rays and the supernatants were transferred to unirradiated HFL-1 cells, a bystander adaptive response was observed against 2 or 4 Gy of $X$ rays. This shows that medium from irradiated cells, which contains the currently unknown cytotoxic bystander factor(s), can induce an adaptive response against a subsequent direct dose.

The aim of this study was to investigate whether a priming dose of irradiated cell conditioned medium (ICCM) could induce an adaptive response against a subsequent challenge dose of ICCM. Clonogenic survival and markers of apoptosis studied previously in our laboratory for single ICCM exposures were investigated to determine whether these end points could be modified by giving a low priming dose of ICCM before the challenge ICCM dose $(18,26)$. $\mathrm{N}$-Acetylcysteine (NAC), a reactive oxygen species (ROS) inhibitor, was added to the ICCM during the "priming" phase to assess the role of ROS in the adaptive response.

\section{MATERIALS AND METHODS}

\section{Cell Culture}

Human keratinocytes immortalized with the HPV virus were originally obtained as a kind gift from Dr. J. Di Paolo, NIH, Bethesda, MD (27). HPV-G cells were cultured in Dulbecco's MEM:F12 medium (1:1) (Sigma, Dorset, UK) containing $10 \%$ fetal calf serum (Gibco, Irvine, UK) 1000 IU $1 \%$ penicillin-streptomycin solution (Gibco), $2 \mathrm{mM}$ L-glutamine (Gibco), and $1 \mu \mathrm{g} / \mathrm{ml}$ hydrocortisone (Sigma) Cells were maintained in an incubator at $37^{\circ} \mathrm{C}$ with $95 \%$ humidity and $95 \%$ air $/ 5 \% \mathrm{CO}_{2}$. Subculture was routinely performed when cells were $80-100 \%$ confluent using a $1: 1$ solution of $0.25 \%$ trypsin and $1 \mathrm{mM}$ versene at $37^{\circ} \mathrm{C}$.

\section{Irradiation}

Cells were irradiated in T-25 flasks (Nunc, Uden, Denmark) containing $5 \mathrm{ml}$ of culture medium at room temperature using a cobalt-60 teletherapy source at St. Luke's Hospital. Control flasks were sham-irradiated. The dose rate during the experiments was approximately $1.8 \mathrm{~Gy} / \mathrm{min}$. For the 0.5 - and 5-Gy doses, the source-to-flask distance was $80 \mathrm{~cm}$. For the 5-mGy dose, an extended source-to-flask distance of $170 \mathrm{~cm}$ was used. The time required to deliver the 5-mGy dose was around $0.013 \mathrm{~min}$. TLDs were used to confirm that the appropriate dose was delivered. Once irradiated, the cells were immediately returned to the incubator.

\section{Harvesting of ICCM}

Donor flasks containing approximately $2 \times 10^{5}$ cells were irradiated or sham-irradiated $6 \mathrm{~h}$ after plating. Medium from irradiated and unirradiated cells was poured off donor flasks $1 \mathrm{~h}$ after irradiation and filtered through a $0.22-\mu \mathrm{m}$ filter to ensure that no cells or other debris were still present in the medium. This filtrate was stored at $-80^{\circ} \mathrm{C}$ in aliquots and thawed when required.

Experimental Procedure

Single radiation/ICCM exposures. Control cells were either sham-irradiated or exposed to unirradiated cell conditioned medium (0 Gy ICCM). Treated cells were either directly irradiated or exposed to ICCM at doses of 0.5 and $5 \mathrm{~Gy}$.

Primed samples (direct radiation). Control cells were sham-irradiated followed by a further sham irradiation $24 \mathrm{~h}$ later (Fig. 1). Treated cells were irradiated to priming doses of $5 \mathrm{mGy}$ or 0.5 Gy followed by a challenge dose of 0.5 Gy or 5 Gy 24 h later (Fig. 1).

Primed samples (ICCM). Control cells were exposed to 0 Gy ICCM for $24 \mathrm{~h}$. The medium was then removed and the cells were exposed to a further 0-Gy ICCM dose (Fig. 1). Treated cells were exposed to $5 \mathrm{mGy}$ or 0.5 Gy ICCM for $24 \mathrm{~h}$, the medium was then removed and the cells were exposed to a further 0.5 - or 5-Gy ICCM dose (Fig. 1). 
EFFECT OF IRRADIATED CELL CONDITIONED MEDIUM ON RADIATION RESPONSE

\section{Clonogenic Assay}

Four hundred HPV-G cells were plated in $4 \mathrm{ml}$ of medium in T-25 flasks (Nunc) for survival assays using the clonogenic assay technique of Puck and Marcus (28). These cells either were directly irradiated with 5 mGy, 0.5 Gy or 5 Gy or received $3 \mathrm{ml}$ of ICCM harvested from cells irradiated with $0 \mathrm{~Gy}, 5 \mathrm{mGy}, 0.5$ Gy or 5 Gy as described previously. Cells were left for $24 \mathrm{~h}$ at $37^{\circ} \mathrm{C}$. This medium was then removed and replaced with a higher dose of ICCM or with control medium. Cells were then left for 7 days in an incubator at $37^{\circ} \mathrm{C}$. The cells were then stained with carbol fuschin (BDH, Poole, UK) and the colonies were counted.

Corrections for multiplicity were not performed since previous work showed that cellular multiplicity does not affect the plating efficiency of these cells because they do not show independent survival $(29,30)$.

\section{Inhibition of Reactive Oxygen Species}

HPV-G cells were incubated with 0.5 Gy ICCM containing $0.5 \mathrm{mM}$ $\mathrm{N}$-acetylcysteine (NAC) (Sigma) for $24 \mathrm{~h}$. This medium was then removed and replaced with a higher dose of ICCM. The clonogenic survival assay was carried out as described above.

\section{Measurement of Calcium Flux}

Intracellular calcium levels were measured using two calcium-sensitive dyes, Fluo-3 and Fura Red (Molecular Probes, Leiden, Netherlands). Fluo-3 increases in intensity upon binding to calcium. Fura Red decreases in intensity upon binding to calcium. The ratio of Fluo 3 to Fura Red gives a good indication of intracellular calcium levels (31). HPV-G cells were seeded at high concentrations (approximately $2 \times 10^{5}$ cells) on glass cover slips (diameter $24 \mathrm{~mm}$ ) and incubated in normal culture medium until the cells had attached. This medium was then removed and replaced with $0.5 \mathrm{~Gy}$ ICCM for $24 \mathrm{~h}$ at $37^{\circ} \mathrm{C}$. Controls were exposed to $0 \mathrm{~Gy}$ ICCM. The HPV-G cells were then washed twice in a $\mathrm{Ca}^{2+} / \mathrm{Mg}^{2+}$ buffer $\left(130 \mathrm{~m} M \mathrm{NaCl}, 5 \mathrm{~m} M \mathrm{KCl}, 1 \mathrm{~m} M \mathrm{Na}_{2} \mathrm{HO}_{4}, 1 \mathrm{~m} M \mathrm{MgCl}_{2}\right.$ and $1 \mathrm{~m} M$ $\mathrm{CaCl}_{2}$ ). The cells were then loaded with $3 \mu M$ Fluo-3 and $3 \mu M$ Fura Red for $1 \mathrm{~h}$ at $37^{\circ} \mathrm{C}$. The dyes were then removed and washed twice in $\mathrm{Ca}^{2+} / \mathrm{Mg}^{2+}$ buffer. The cover slips were then inserted into custom-designed petri dishes, which allowed imaging through the glass cover slip in the base of the dish. The cells were then exposed to 5 Gy ICCM after a baseline calcium level was established. Using a Zeiss LSM 510 confocal microscope, Fluo 3 and Fura Red were excited at $488 \mathrm{~nm}$ and fluorescence was recorded simultaneously at $525 \mathrm{~nm}$ and $660 \mathrm{~nm}$. Ratio images were recorded every $2 \mathrm{~s}$ for $5 \mathrm{~min}$. Ratio values were determined for each individual cell using Zeiss LSM software.

\section{Measurement of Mitochondrial Membrane Potential}

Mitochondrial membrane potential was measured using a green fluorescent dye, Rhodamine 123 (Molecular Probes), which accumulates in active mitochondria with high mitochondrial membrane potential (32). HPV-G cells were seeded at high concentrations (approximately $2 \times 10^{5}$ cells) on glass cover slips (diameter $24 \mathrm{~mm}$ ) and incubated in normal culture medium until the cells had attached. This medium was then removed and replaced with $0.5 \mathrm{~Gy}$ ICCM for $24 \mathrm{~h}$ at $37^{\circ} \mathrm{C}$. The $0.5 \mathrm{~Gy}$ ICCM was then removed, and HPV-G cells were exposed to 5 Gy ICCM for $6 \mathrm{~h}$ at $37^{\circ} \mathrm{C}$. The $5 \mathrm{~Gy}$ ICCM was then removed, and the cells were washed with a $\mathrm{Ca}^{2+} / \mathrm{Mg}^{2+}$ buffer $(130 \mathrm{~m} M \mathrm{NaCl}, 5 \mathrm{mM} \mathrm{KCl}, 1 \mathrm{mM}$ $\mathrm{Na}_{2} \mathrm{HO}_{4}, 1 \mathrm{mM} \mathrm{MgCl}$ and $\left.1 \mathrm{~m} M \mathrm{CaCl}_{2}\right)$. The HPV-G cells were then loaded with $5 \mu M$ Rhodamine 123 for $30 \mathrm{~min}$ at $37^{\circ} \mathrm{C}$. The dye was then removed, the cells were washed in $\mathrm{Ca}^{2+} / \mathrm{Mg}^{2+}$ buffer twice, and the cover slips were inserted into custom-designed petri dishes, which allowed imaging through the glass cover slip in the base of the dish. Using a Zeiss LSM confocal microscope, the HPV-G cells were excited at $488 \mathrm{~nm}$ and fluorescence emission was recorded at $525 \mathrm{~nm}$. Three fields of view were recorded for each sample and repeated as three independent experiments. The intensity of green fluorescence was measured for each cell using
Zeiss LSM software. Control fluorescence was set to $100 \%$. All fluorescence was normalized to the control.

\section{Measurement of Mitochondrial Mass per Cell}

Mitochondrial mass was measured using a fluorescent dye, MitoTracker Green FM (Molecular Probes), which accumulates in the mitochondrial matrix, where it covalently binds to mitochondrial proteins by reacting with free thiol groups of cysteine residues. An increase in green fluorescence clearly identifies an increase in mitochondrial mass (33). HPV-G cells were seeded at high concentrations (approximately $2 \times 10^{5}$ cells) on glass cover slips (diameter $24 \mathrm{~mm}$ ) and incubated in normal culture medium for $3 \mathrm{~h}$ until the cells had attached. This medium was then removed. The cells were incubated at $37^{\circ} \mathrm{C}$ with $5 \mathrm{mGy}$ ICCM for $24 \mathrm{~h}$. This medium was then removed, and cells were exposed to $0.5 \mathrm{~Gy}$ ICCM for $18 \mathrm{~h}$. The ICCM was then removed, and the cells were washed in $\mathrm{Ca}^{2+} / \mathrm{Mg}^{2+}$ buffer $\left(130 \mathrm{~m} M \mathrm{NaCl}, 5 \mathrm{~m} M \mathrm{KCl}, 1 \mathrm{~m} M \mathrm{Na}_{2} \mathrm{HPO}_{4}, 1 \mathrm{~m} M\right.$ $\mathrm{MgCl}_{2}$ and $1 \mathrm{mM} \mathrm{CaCl}$ ). Cells were loaded with Mito Tracker Green FM $(150 \mathrm{nM})$ made up in $\mathrm{Ca}^{2+} / \mathrm{Mg}^{2+}$ buffer for $20 \mathrm{~min}$ at $37^{\circ} \mathrm{C}$ and subsequently washed twice in buffer. The cover slips were then inserted into custom-designed petri dishes, which allowed imaging through the glass cover slip in the base of the dish. Using a Zeiss LSM 510 confocal microscope, Mito Tracker Green FM was excited at $488 \mathrm{~nm}$ and fluorescence emission was recorded at $525 \mathrm{~nm}$. Three fields of view were recorded for each dish. Three independent experimental runs were carried out. The intensity of green fluorescence was measured using Zeiss LSM software. The mean fluorescence was divided by the number of cells in the field of view. An increase in fluorescence intensity indicated an increase in mitochondrial mass per cell (33). Control fluorescence was set to $100 \%$, and all data were normalized to the control.

\section{Distribution of Mitochondria}

Mito Tracker Green FM was used to stain the mitochondria in HPV-G cells as described above. Z-stacks were recorded using the Zeiss LSM 510 confocal microscope to confirm the location of mitochondria in the cell. The location of the mitochondria in the cell was scored as either being located diffusely in the cytoplasm or as being in a perinuclear location around the nucleus. Five hundred cells were scored for each of three independent experimental runs. The slides were coded and scored blind. The percentage of cells with either cytoplasmic distribution or perinuclear distribution was calculated.

\section{Statistics}

Data are reported as means \pm standard errors of three independent experiments performed in triplicate. Significance was determined by a Student's unpaired $t$ test, and the differences were considered significant if $P \leq 0.05$.

\section{RESULTS}

HPV-G cells primed with either a 5-mGy or a 0.5 -Gy direct dose before a challenge dose of either 0.5 Gy or 5 Gy showed a significant increase in survival compared to those cells that received a 0.5 - or 5-Gy direct dose only, indicating an adaptive response (Table 1). Exposure of HPV-G cells to either $5 \mathrm{mGy}$ or $0.5 \mathrm{~Gy}$ ICCM as a priming dose followed by a challenge dose of 0.5 or 5 Gy ICCM resulted in an increase in survival compared to those cells exposed to 0.5 or 5 Gy ICCM only, again indicating an adaptive response (Table 1).

To determine the role of ROS, HPV-G cells were pretreated with $5 \mathrm{mGy}$ or 0.5 Gy ICCM containing NAC in 
TABLE 1

Clonogenic Survival of HPV-G Cells

\begin{tabular}{lcc}
\hline \multicolumn{1}{c}{ Dose } & Direct radiation & ICCM \\
\hline $0 \mathrm{~Gy}$ & $100(33 \pm 1.1)$ & $100(31 \pm 2)$ \\
$0.5 \mathrm{~Gy}$ & $74 \pm 3 \%^{*}$ & $68 \pm 2 \%^{*}$ \\
$5 \mathrm{~Gy}$ & $15 \pm 2 \%^{*}$ & $66 \pm 3 \%^{*}$ \\
$0 \mathrm{~Gy}+0 \mathrm{~Gy}$ & $100(32 \pm 1)$ & $100(33 \pm 1)$ \\
$5 \mathrm{mGy}+1 \mathrm{~Gy}$ & $101 \pm 2 \%^{*}$ & $79 \pm 6 \%^{*}$ \\
$1 \mathrm{~Gy}+5 \mathrm{~Gy}$ & $53 \% \pm 6^{*}$ & $80 \pm 26 \%^{*}$ \\
\hline
\end{tabular}

Notes. Actual plating efficiencies for controls are shown in parentheses. $* P<0.05$. For single exposures, the irradiated samples were tested against the unirradiated samples. The primed exposures were tested against the unprimed exposures.

the priming phase only and then exposed to a challenge dose of 0.5 or 5 Gy ICCM. No significant reduction in survival was observed, indicating that NAC can prevent bystander-induced cell death (Table 2 ).

Rapid calcium fluxes were observed in HPV-G cells pre-
TABLE 2

Clonogenic Survival of HPV-G Cells Primed with ICCM Containing NAC for $24 \mathrm{~h}$ Followed by Exposure to ICCM for 7 Days

\begin{tabular}{lc}
\hline \multicolumn{1}{c}{ Dose } & Survival \\
\hline (0 Gy ICCM + NAC) + 0 Gy ICCM & $100 \pm 5 \%$ \\
$(5$ mGy ICCM + NAC $)+1$ Gy ICCM & $102 \pm 5 \%$ \\
$(0.5$ Gy ICCM + NAC $)+5$ Gy ICCM & $115 \pm 9 \%$ \\
\hline
\end{tabular}

treated with $5 \mathrm{mGy}$ or $0.5 \mathrm{~Gy}$ ICCM and then exposed to 0.5 or 5 Gy ICCM. Figure 2 shows the characteristic calcium flux. This calcium increase lasts approximately $140 \mathrm{~s}$, with calcium levels in all responding cells returning to baseline levels. No calcium fluxes were observed in the control sample, which received 0 Gy ICCM for $24 \mathrm{~h}$ followed by 0 Gy ICCM. Four characteristic patterns of response were observed in the primed samples; $21 \%$ of the exposed population did not respond to the 5-Gy ICCM
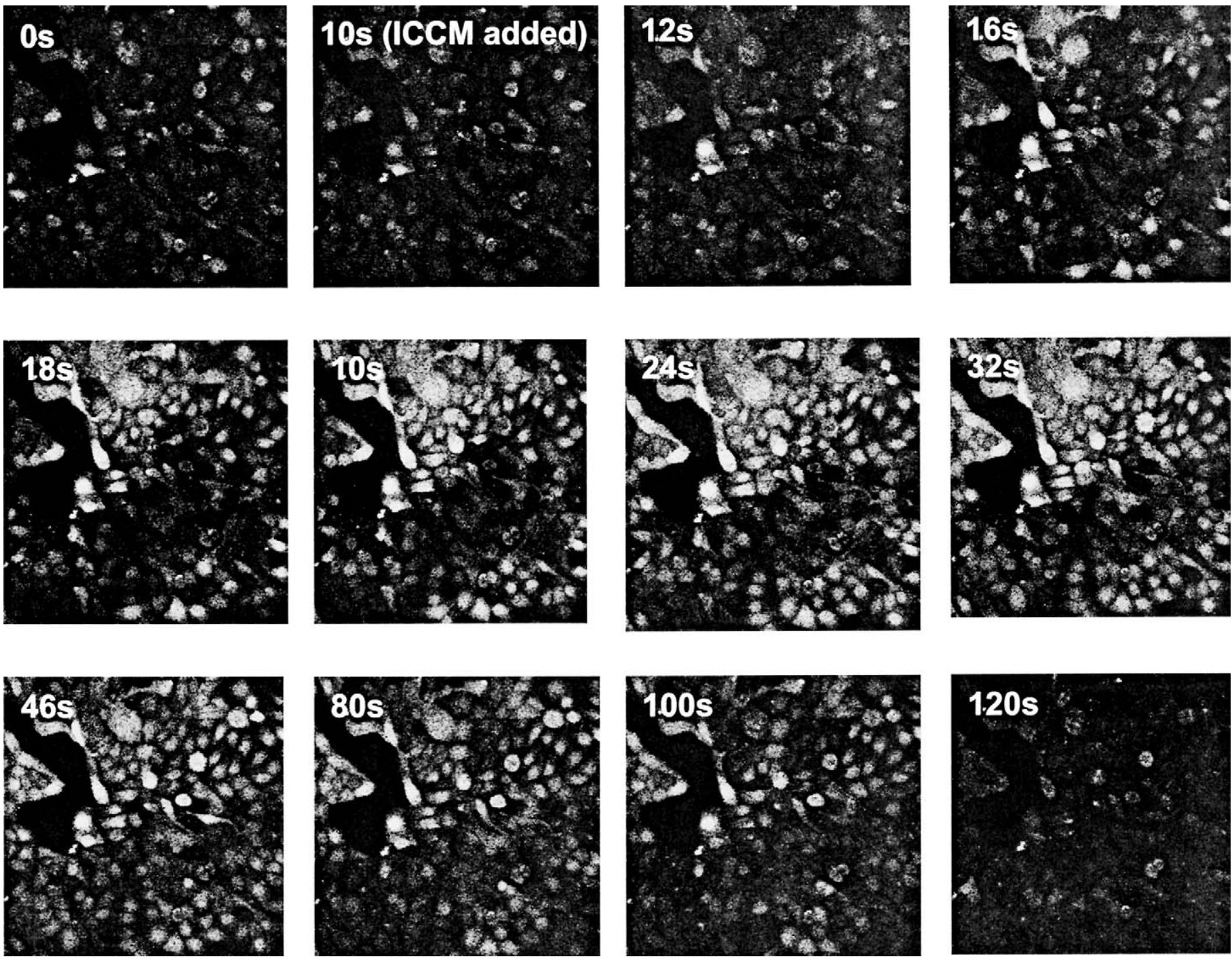

FIG. 2. Real-time fluorescence confocal images showing intracellular calcium levels in HPV-G cells exposed to a priming dose of 0.5 Gy ICCM for $24 \mathrm{~h}$ followed by 5 Gy ICCM over $120 \mathrm{~s}$. 
EFFECT OF IRRADIATED CELL CONDITIONED MEDIUM ON RADIATION RESPONSE

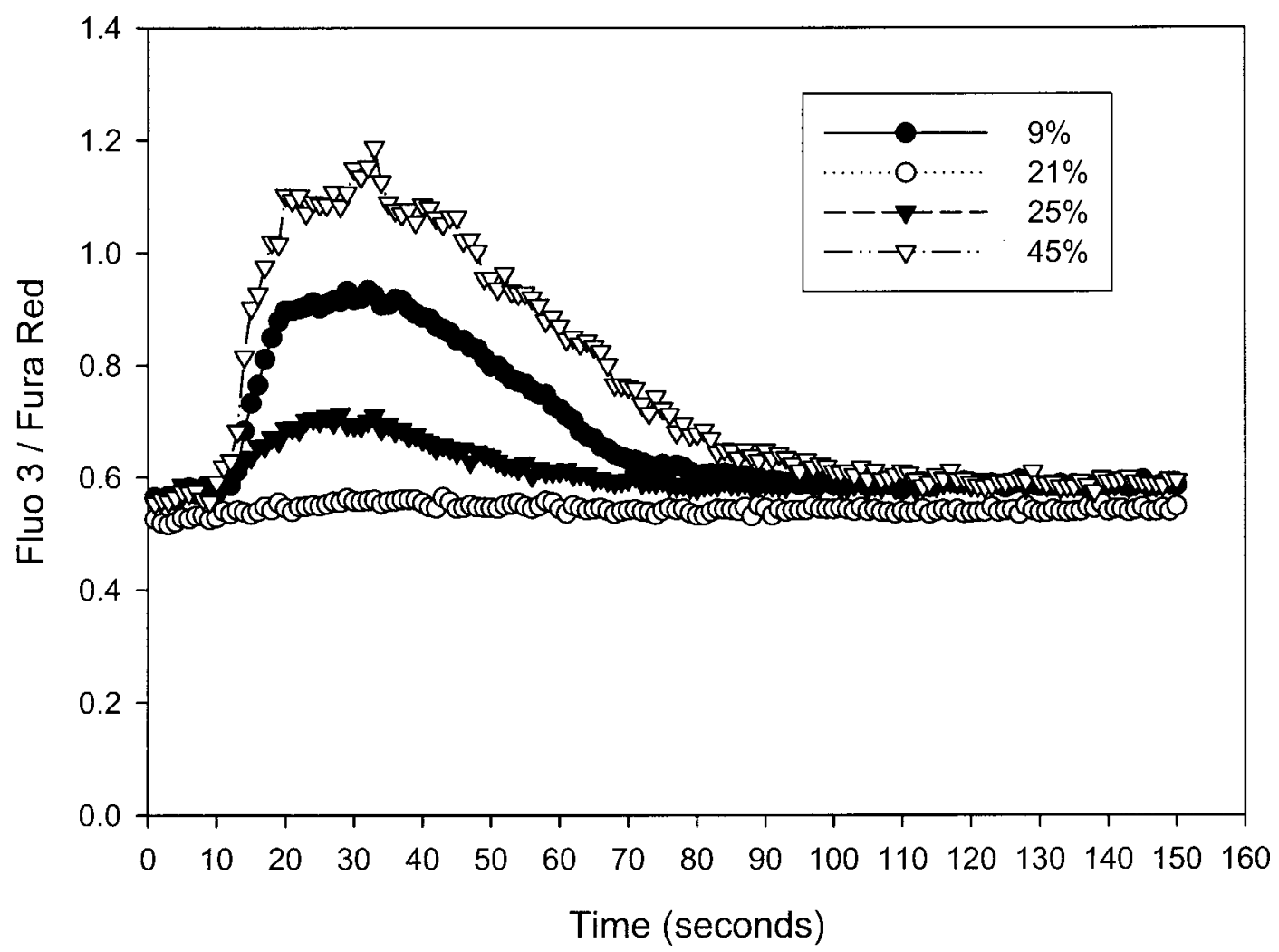

FIG. 3. Magnitude of the varying calcium fluxes induced in HPV-G cells when exposed to 0.5 Gy ICCM for $24 \mathrm{~h}$ and then to 5 Gy ICCM. An increase in the ratio of Fluo 3 to Fura Red is indicative of an increase in calcium levels.

dose, and these nonresponding cells were located together in clusters; $25 \%$ of cells increased from a baseline ratio value of 0.5 to $0.8,45 \%$ of cells increased from a baseline ratio value of 0.5 to 1 , and $9 \%$ of cells increased from a baseline ratio value of 0.5 to 1.2 (Fig. 3). An interesting observation was that regardless of the magnitude of the calcium flux, the lag time needed for the response to occur, the time taken for the calcium to peak, and the time taken for the calcium levels to return to baseline values were more or less the same in all cases.

Exposure of HPV-G cells to a single ICCM dose resulted in a significant reduction in mitochondrial membrane potential after $6 \mathrm{~h}$ (Table 3). Pretreatment of HPV-G cells with 0.5 Gy ICCM for $24 \mathrm{~h}$ followed by an exposure to $5 \mathrm{~Gy}$

TABLE 3

Percentage Fluorescence Levels as Indicated by JC-1 in HPV-G Cells Exposed to Various Doses of Radiation or ICCM

\begin{tabular}{lc}
\hline \multicolumn{1}{c}{ Dose } & Fluorescence \\
\hline 0 Gy & $100 \pm 1 \%$ \\
1 Gy & $85 \pm 1 \% *$ \\
5 Gy & $89 \pm 1 \% *$ \\
0 Gy ICCM + 0 Gy ICCM & $100 \pm 9 \%$ \\
1 Gy ICCM + 5 Gy ICCM & $91 \pm 9 \%$ \\
\hline
\end{tabular}

Notes. A decrease in cellular fluorescence is indicative of a loss of mitochondrial membrane potential. $* P<0.05$.
ICCM for $6 \mathrm{~h}$ resulted in a small but nonsignificant reduction in mitochondrial membrane potential compared to the 0 Gy ICCM control, indicating an adaptive response (Table 3).

Exposure of HPV-G cells to $5 \mathrm{mGy}$ and $0.5 \mathrm{~Gy}$ ICCM but not $5 \mathrm{~Gy}$ ICCM for $18 \mathrm{~h}$ resulted in an increase in mitochondrial mass and a change in mitochondrial distribution from a diffuse location in the cytoplasm (as observed in the control) to a perinuclear location (Table 4). Pretreatment of HPV-G cells with 5 mGy ICCM for $24 \mathrm{~h}$ followed by exposure to 0.5 Gy ICCM for $18 \mathrm{~h}$ also caused a significant increase in mitochondrial mass and a change in the location of the mitochondria (Table 4).

TABLE 4

Percentage Fluorescence Levels and Percentage Cells with Mitochondria in Perinuclear Location as Indicated by Mito Tracker Green FM in HPV-G Cells after Exposure to Various Doses of Radiation or ICCM

\begin{tabular}{llc}
\hline \multicolumn{1}{c}{ Dose } & Fluorescence & $\begin{array}{c}\text { Cells with mitochondria } \\
\text { in perinuclear location }\end{array}$ \\
\hline 0 Gy & $100 \pm 11.8 \%$ & $7 \pm 1 \%$ \\
5 mGy & $128 \pm 29 \% *$ & $38 \pm 3 \% *$ \\
1 Gy & $178 \pm 18 \%$ & $9 \pm 2 \%$ \\
0 Gy ICCM + 0 Gy ICCM & $100 \pm 22 \%$ & $12 \pm 4 \%$ \\
5 mGy ICCM + 1 Gy ICCM & $363 \pm 9 \%$ & $63 \pm 7 \% *$ \\
\hline
\end{tabular}

Notes. An increase in cellular fluorescence is indicative of an increase in mitochondrial mass. * $P<0.05$. 
MAGUIRE ET AL.

\section{DISCUSSION}

The results show that exposure of HPV-G cells to a low priming dose of ICCM or direct radiation resulted in modulation of radiation-induced responses, suggesting an adaptive response.

Clonogenic survival results indicated a significant reduction in the amount of cell killing by the second dose for both the irradiated and ICCM-treated samples. This implies the presence of both a radiation-induced adaptive response and an ICCM-induced adaptive response. Radiation-induced adaptive responses are commonly reported in the literature $(1,2)$. However, there are few reports of an ICCMinduced adaptive response against a direct dose (23-25). The magnitude of the observed "ICCM adaptive response" was $10-15 \%$ sparing of cell survival. Mitchell et al. (24) and Iyer and Lehnert (25) reported "bystander-induced adaptive responses" induced by a priming treatment of supernatant from cells irradiated at doses of the order of centigrays. This work shows that ICCM derived from cells irradiated with $5 \mathrm{mGy}$ can induce bystander adaptive responses against a further challenge dose of ICCM. No significant loss of clonogenic survival in HPV-G cells was observed when cells were incubated with ICCM containing NAC in the priming phase for $24 \mathrm{~h}$ followed by ICCM only. NAC, a thiol-containing antioxidant, has been shown to protect cells against damage caused by ROS, although the exact ROS involved is currently unknown (34). Data from our laboratory have shown that bystander-induced cell death can be blocked in HPV-G cells incubated in ICCM containing NAC (35). Iyer and Lehnert (25) suggest that bystander-induced adaptive responses could be due to increased levels of AP DNA endonucleases (APE), induced as a result of an increase in sublethal levels of ROS. Lyng et al. (18) reported an increase in ROS after exposure of HPV-G cells to ICCM. Therefore, cells displaying bystander adaptive responses may be more efficient at repairing at least some forms of DNA damage caused by ROS.

When HPV-G cells were pretreated with 0.5 Gy ICCM for $24 \mathrm{~h}$ and then exposed to 5 Gy ICCM, a significant calcium flux was observed, an event associated with initiation of the cascade leading to apoptosis (36). Lyng et al. (18) showed that exposure to ICCM causes an increase in intracellular calcium. From this work and the results in the present paper, it is concluded that HPV-G cells have the ability to produce repetitive calcium fluxes when exposed to ICCM followed by ICCM, causing a secondary cascade of cellular responses. Four types of calcium response were observed, including three different magnitudes of increase in calcium and a nonresponding population of cells. Only $9 \%$ of the exposed cells displayed a calcium increase of the same magnitude as for a single ICCM exposure. Dolmetsch et al. (37) reported that the amplitude and duration of calcium signals in B lymphocytes controls differential activation of transcription factors such as c-Jun N-terminal kinase. The differential activation results from differences in the $\mathrm{Ca}^{2+}$ sensitivity and the kinetic pathway of the observed calcium flux. The MAP kinase pathway has been shown to be activated in bystander cells $(38,39)$. Therefore, it can be postulated that the different amplitudes of calcium responses observed may result in different levels of activation of transcription factors. When HPV-G cells were exposed to $0.5 \mathrm{~Gy}$ ICCM for $24 \mathrm{~h}$ and then exposed to $5 \mathrm{~Gy}$ ICCM, it was observed that approximately $21 \%$ of cells did not respond to the 5 Gy ICCM. These cells maintained their baseline level of calcium throughout the exposure and were located together in clusters. Protective proteins, such as BCL2, may have been activated in the nonresponding cells that protect against the second ICCM dose. Apoptosis suppressed by BCL2 has been correlated with the regulation of nuclear and cytosolic calcium $(40,41)$. ICCM has been observed to induce BCL2 expression in HPV-G cells (35). Interestingly, the observed time for cells to respond, the time it took for the responding cells to peak in magnitude, and the time it took to return to the baseline calcium level were the same in all cases. Since the uptake of extracellular calcium is a regulated physiological process, this illustrates that HPV-G cells have the ability to maintain and regulate their extracellular calcium uptake for multiple exposures to ICCM.

Exposure of HPV-G cells for $24 \mathrm{~h}$ to $0.5 \mathrm{~Gy}$ ICCM followed by 5 Gy ICCM for $6 \mathrm{~h}$ resulted in a small but nonsignificant loss of mitochondrial membrane potential. Lyng et al. (18) reported a significant loss of mitochondrial membrane potential after $6 \mathrm{~h}$ exposure to $0.5 \mathrm{~Gy}$ ICCM or $5 \mathrm{~Gy}$ ICCM. The reason that the loss of mitochondrial membrane potential found here was not significant is probably that anti-apoptosis proteins such as BCL2 are already actively expressed in the pre-exposed cells, as discussed above.

Exposure of HPV-G cells to $5 \mathrm{mGy}$ ICCM for $24 \mathrm{~h}$ followed by 0.5 Gy ICCM for $18 \mathrm{~h}$ induced a significant increase in mitochondrial mass. A significant change in mitochondrial location from a diffuse cytoplasmic location to a dense perinuclear location was also observed. Maguire et al. (35) reported an increase in mitochondrial mass and change in mitochondrial location for ICCM doses $\leq 0.5$ Gy ICCM. Interestingly, the ICCM-induced adaptive response eliminated the appearance of markers of apoptosis such as mitochondrial membrane potential but not changes in mitochondrial mass. An increase in mitochondrial mass has been linked to genomic instability and mitochondrial biogenesis (42). It has been shown previously that although cell survival could be increased after a priming dose, no abrogation of transformation frequency was found (21). This questions the long-term fate of the progeny of these adapted cells.

In summary, this study has shown that bystander signals produced by irradiated cells can induce an adaptive response in unirradiated cells to a subsequent exposure to bystander signals. 
EFFECT OF IRRADIATED CELL CONDITIONED MEDIUM ON RADIATION RESPONSE

\section{ACKNOWLEDGMENTS}

We are grateful to St. Luke's Hospital Rathgar, Dublin, for continued access to their Cobalt 60 source. This work has been funded by Science Foundation Ireland. The Focas Institute is funded under the Programme for Research in Third Level Institutions (PRTLI), administered by the HEA, of the National Development Plan 2000-2006 with assistance from the European Regional Development Fund.

Received: January 18, 2006; accepted: October 16, 2006

\section{REFERENCES}

1. G. Olivieri, J. Bodycote and S. Wolff, Adaptive response of human lymphocytes to low concentrations of radioactive thymidine. Science 223, 594-597 (1984).

2. J. D. Shadley and S. Wolff, Very low doses of X-rays can cause human lymphocytes to become less susceptible to ionizing radiation. Mutagenesis 2, 95-96 (1987).

3. M. S. Sasaki, On the reaction kinetics of the radioadaptive response in cultured mouse cells. Int. J. Radiat. Biol. 68, 281-291 (1995).

4. E. I. Azzam, G. P. Raaphorst and R. E. J. Mitchel, Radiation-induced adaptive response for protection against micronucleus formation and neoplastic transformation in $\mathrm{C} 3 \mathrm{H} 10 \mathrm{~T} 1 / 2$ mouse embryo cells. $R a-$ diat. Res. 138 (Suppl.), S28-S31 (1994).

5. E. I. Azzam, S. M. de Toledo, G. P. Raaphorst and R. E. J. Mitchel, Low-dose ionizing radiation decreases the frequency of neoplastic transformation to a level below the spontaneous rate in $\mathrm{C} 3 \mathrm{H}$ 10T1/2 cells. Radiat. Res. 146, 369-373 (1996).

6. R. E. J. Mitchel, J. S. Jackson, R. A. McCann and D. R. Boreham, The adaptive response modifies latency for radiation-induced myeloid leukemia in CBA/H mice. Radiat. Res. 152, 273-279 (1999).

7. J. D. Shadley, V. Afzal and S. Wolff. Characterization of adaptive response to ionizing radiation by low doses of $\mathrm{X}$ rays to human lymphocytes. Radiat. Res. 111, 511-517 (1987).

8. L. Cai and P. Wang, Induction of cytogenetic adaptive response in germ cells of irradiated mice with low-dose rate of chronic in $\gamma$ irradiation and its biological influence on radiation-induced DNA or chromosomal damage and cell killing in their offspring. Mutagenesis 10, 95-100 (1995).

9. T. Ikushima, Radio-adaptive response: Characterization of a cytogenetic repair induced low-level ionizing radiation in cultured Chinese hamster cells. Mutat. Res. 227, 241-246 (1989).

10. H. E. Kleckowska and F. R. Althaus, The role of poly(ADP-ribosyl)ation in the adaptive response. Mutat. Res. 358, 215-221 (1996).

11. S. Wolff, J. K. Wiencke, V. Afzal, J. Youngblom and F. Corte, The adaptive response of human lymphocytes to very low doses of ionizing irradiation: A case of induced chromosomal repair with the induction of specific proteins. In Low Dose Radiation: Biological Bases of Risk Assessment (K. F. Baverstock and J. W. Stather, Eds.), pp. 446-454. Taylor \& Francis, London, 1989.

12. T. Ikushima, H. Aritomi and J. Morisita, Radioadaptive response: Efficient repair of radiation-induced DNA damages in adapted cells. Mutat. Res. 358, 193-198 (1996).

13. C. Mothersill and C. B. Seymour, Radiation-induced bystander effects: Past history and further directions. Radiat. Res. 155, 759-767 (2001).

14. H. Nagasawa and J. B. Little, Induction of sister chromatid exchanges by extremely low doses of alpha particles. Cancer Res. 52, 63946396 (1992).

15. S. A. Lorimore, M. A. Kadhim, D. A. Pocock, D. Papworth, D. L. Stevens, D. T. Goodhead and E. G. Wright, Chromosomal instability in the descendants of unirradiated surviving cells after $\alpha$-particle irradiation. Proc. Natl. Acad. Sci. USA 95, 5730-5733 (1998).

16. E. I. Azzam, S. M. de Toledo, T. Gooding and J. B. Little, Intracellular communication is involved in the bystander regulation of gene expression in human cells exposed to very low fluences of alpha particles. Radiat. Res. 150, 497-504 (1998).
17. C. B. Seymour and C. Mothersill, Delayed expression of lethal mutations and genomic instability in the progeny of human epithelial cells that survived in a bystander killing environment. Radiat. Oncol. Investig. 5, 106-110 (1997).

18. F. M. Lyng, C. B. Seymour and C. Mothersill, Production of a signal by irradiated cells which leads to a response in unirradiated cells characteristic of initiation of apoptosis. Br. J. Cancer 83, 1223-1230 (2000).

19. C. B. Seymour and C. Mothersill, Relative contributions of bystander and targeted cell killing to the low-dose region of the radiation doseresponse curve. Radiat. Res. 153, 508-511 (2000).

20. G. Schettino, M. Folkard, K. M. Prise, B. Vojnovic, K. D. Held and B. D. Michael, Low-dose studies of bystander cell killing with targeted soft X rays. Radiat. Res. 160, 505-511 (2003).

21. S. G. Sawant, G. Randers-Pehrson, N. F. Metting and E. Hall, Adaptive response and the bystander effect induced by radiation in $\mathrm{C} 3 \mathrm{H}$ 10T1/2 cells in culture. Radiat. Res. 156, 177-180 (2001).

22. H. Zhou, G. Randers-Pehrson, C. R. Geard, D. J. Brenner, E. J. Hall and T. K. Hei, Interaction between radiation-induced adaptive response and bystander mutagenesis in mammalian cells. Radiat. Res. 160, 512-516 (2003).

23. C. Mothersill and C. Seymour, Bystander and delayed fractionated radiation exposure. Radiat. Res. 158, 626-633 (2002).

24. S. A. Mitchell, S. A. Marino, D. J. Brenner and E. J. Hall, Bystander effects and adaptive responses in $\mathrm{C} 3 \mathrm{H} 10 \mathrm{~T} 1 / 2$ cells. Int. J. Radiat. Biol. 80, 465-472 (2004).

25. R. Iyer and B. Lehnert, Low dose, low LET ionizing radiation-induced radioadaptation and associated early responses in unirradiated cells. Mutat. Res. 503, 1-9 (2004).

26. C. Mothersill and C. B. Seymour, Medium from irradiated human epithelial cells but not human fibroblasts reduces the clonogenic survival of unirradiated cells. Int. J. Radiat. Biol. 71, 421-427 (1997).

27. L. Pirisi, A. Batova, G. R. Jenkins, J. R. Hodam and K. E. Creek, Increased sensitivity of human keratinocytes immortalized by human papillomavirus type 16 DNA to growth controls by retinoids. Cancer Res. 52, 187-193 (1992).

28. T. T. Puck and P. I. Marcus, Action of X-rays on mammalian cells J. Exp. Med. 103, 653-666 (1956).

29. C. Mothersill and C. Seymour, Survival of human epithelial cells irradiated with Cobalt 60 as microcolonies or single cells. Int. J. Radiat. Biol. 72, 597-606 (1997).

30. R. J. Cummins, C. Mothersill, C. B. Seymour, H. Johns and M. C Joiner, The effect of microcolony size, at time of irradiation, on colony forming ability. Int. J. Radiat. Biol. 75, 225-232 (1999).

31. P. Lipp and E. Niggli, Ratiometric confocal Ca-measurements with visible wavelength indicators in cardiac myocytes. Cell Calcium $\mathbf{1 4}$ 359-372 (1993).

32. C. Ferlini, S. Di Cesare, G. Rainaldi, W. Malorni, P. Samoggia, R. Biselli and A. Fattorossi, Flow cytometric analysis of the early phase of apoptosis by cellular and nuclear techniques. Cytometry 24, 106115 (1996).

33. J. Bereiter-Hahn and M. Voth, Dynamics of mitochondria in living cells: Shape changes, dislocations, fusion, and fission of mitochondria. Microsc. Res. Tech. 15, 198-219 (1994).

34. N. Morley, A. Curnow, L, Salter, S. Campbell and D. Gould, NAcetyl-L-cysteine prevents DNA damage induced by UVA, UVB and visible radiation in human fibroblasts. J. Photochem. Photobiol. 72, 55-60 (2003).

35. P. Maguire, C. Mothersill, C. Seymour and F. M. Lyng, Medium from irradiated cells induces dose-dependent mitochondrial changes and BCL2 responses in unirradiated human keratinocytes. Radiat. Res. 163, 384-390 (2005).

36. D. M. Ojcius, A. Zychlinsky, L. M. Zheng and J. D. Young, Ionophore induced apoptosis: Role of DNA fragmentation and calcium fluxes. Exp. Cell Res. 197, 43 (1991).

37. R. E. Dolmetsch, R. S. Lewis, C. C. Goodnow and J. I. Healy, Differential activation of transcriptional factors induced by $\mathrm{Ca}^{2+}$ response amplitude and duration. Nature 386, 855-858 (1997). 
MAGUIRE $E T A L$.

38. E. I. Azzam, S. M. de Toledo, D. R. Spitz and J. B. Little, Oxidative metabolism modulates signal transduction and micronucleus formation in bystander cells from alpha-particle-irradiated normal human fibroblast cultures. Cancer Res. 62, 5436-5442 (2002).

39. F. M. Lyng, P. Maguire, B. McClean, C. Seymour and C. Mothersill, The involvement of calcium and MAP kinase signaling pathways in the production of radiation-induced bystander effects. Radiat. Res. 165, 400-409 (2006)

40. G. Baffy, T. Miyashita, J. R. Williamson and J. C. Reed, Apoptosis induced by withdrawal of interleukin-3 (IL-3) from an IL-3-depen- dent hematopoietic cell line is associated with the repartitioning of intracellular calcium and is blocked by enforced BCL-2 oncoprotein production. J. Biol. Chem. 268, 6511-6519 (1993).

41. M. C. Matin, A. Fernandez, R. J. Bick, S. Brisbay, M. Buja, M. Snuggs, D. J. McConkey, A. C. V. Eschenbach, M. J. Keating and T. J. McDonnell, Apoptosis suppressed by Bcl-2 is correlated with the regulation of nuclear and cytosolic $\mathrm{Ca}^{2+}$. Oncogene 12, 22592266 (1996).

42. C. Limoli, E. Giedzinski, W. F. Morgan, S. G. Swarts, D. D. Jones and W. Hyun, Persistent oxidative stress in chromosomally unstable cells. Cancer Res. 63, 3107-3111 (2003). 